\section{Key words}

\section{enals}

ketimines

NHCs

$\gamma$-lactams
H. LV, B. TIWARI, J. MO, C. XING, Y. R. CHI* (NANYANG TECHNOLOGICAL UNIVERSITY, SINGAPORE)

Highly Enantioselective Addition of Enals to Isatin-Derived Ketimines Catalyzed by N-Heterocyclic Carbenes: Synthesis of Spirocyclic $\gamma$-Lactams

Org. Lett. 2012, 14, 5412-5415.

\title{
NHC-Catalyzed Annulation of Isatin N-Boc Ketimines and Enals
}

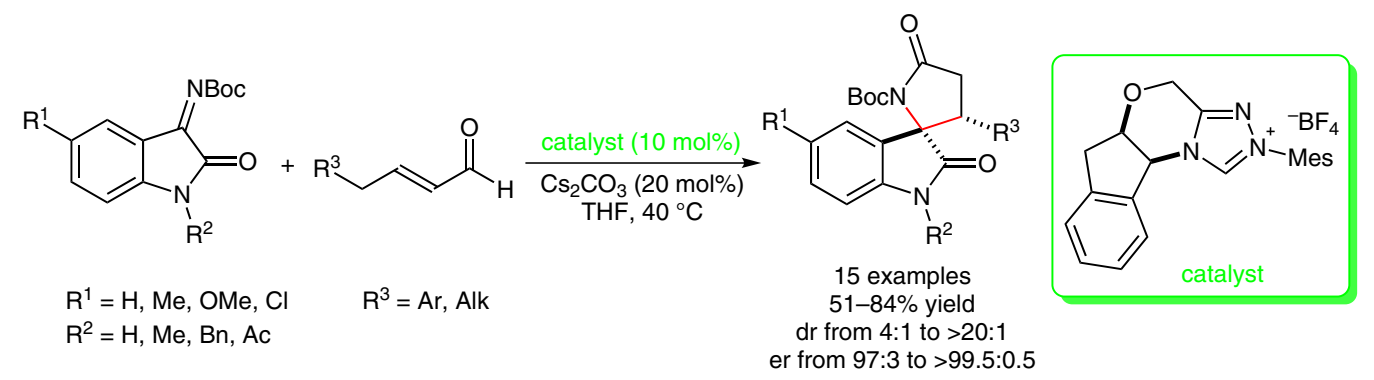

Selected examples:<smiles>CN1C(=O)[C@]2(c3ccccc31)[C@@H](c1ccccc1)CC(=O)N2C(=O)[O-]</smiles>

$83 \%$ yield

$\mathrm{dr}>20: 1$ er $=99.5: 0.5$<smiles>CC(C)(C)OC(=O)N1C(=O)C[C@@H](c2ccccc2)[C@]12C(=O)Nc1ccccc12</smiles>

$64 \%$ yield

$\mathrm{dr}=17: 1 \mathrm{dr}$ $\mathrm{er}=99.5: 0.5$<smiles>CN1C(=O)[C@@]2(c3ccccc31)[C@@H](c1ccco1)CC(=O)N2C(C)(C)C</smiles>

$80 \%$ yield

$\mathrm{dr}>20: 1$ er $=99.5: 0.5$<smiles>C[C@@H]1CC(=O)N(C(C)(C)C)[C@@]12C(=O)N(C)c1ccccc12</smiles>

$64 \%$ yield $\mathrm{dr}=4: 1$ er $=97: 3$

Removal of the Boc protecting group:<smiles>CN1C(=O)[C@@]2(c3ccccc31)[C@@H](c1ccccc1)CC(=O)N2C(=O)c1ccccc1</smiles>

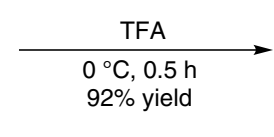<smiles>CN1C(=O)[C@@]2(NC(=O)C[C@H]2c2ccccc2)c2ccccc21</smiles>

Significance: Chi and co-workers report an Nheterocyclic carbene (NHC)-catalyzed annulation of isatin N-Boc imines with enals, which affords spirocyclic oxindole- $\gamma$-lactams bearing one quaternary chiral center in good diastereo- and excellent stereoselectivities (dr up to $>20: 1$ and er $>$ 99.5:0.5). Ketimines and $\gamma$-aryl enals with electron-donating substituents lead to better yield and selectivity compared to electron-withdrawing substituents. The presence of a trace of water is beneficial for the conversion of the reaction. The resulting products can be easily deprotected to free $\gamma$-lactams in high yield.

SYNFACTS Contributors: Benjamin List, Qinggang Wang Synfacts 2013, 9(1), 0104 Published online: 17.12.2012 Dol: 10.1055/s-0032-1317902; Reg-No.: B11512SF
Comment: $\gamma$-Lactams are privileged scaffolds found in naturally occurring and synthetic biologically active compounds. Herein, the authors have developed a novel NHC-catalyzed annulation methodology, which allows for a rapid construction of spirocyclic oxindole- $\gamma$-lactams with high diastereoselectivity and enantioselectivity. More efficient catalysts and the application to more challenging substrates are expected. 